\title{
Research Paper Performance of major crops and changes in cropping pattern in Akola district
}

\section{N.H. GORE, J.V. LEMBHE AND P.L. KOLEKAR}

See end of the paper for authors' affiliations

Correspondence to :

\section{N.H. GORE}

Department of

Agricultural Economics,

College of Agriculture,

Phaltan, SATARA (M.S.)

INDIA

\section{Paper History :}

Received : 23.07.2015;

Revised : 29.07.2015;

Accepted : 20.08.2015
Abstract : The study has been examined the growth rates of area, production and productivity of major crops and changes in cropping pattern in Akola district of Vidarbha. The present study was based on secondary data collected from different government publications. The data covered a period of 15 years i.e., 1995-96 to 2009-10. In all 6 crops were considered for study. These crops covered more than 80 per cent of the total cropped area of the study area. The growth rate was used to examine performance of major crops, Simple tabular analysis was used to examine the changes in cropping pattern in Akola district. The analysis showed that the area under Kharif jowar has found to be decreased in of Akola district. Area under soybean crop was increased in Akola district. The area under wheat has found to be increased and Cotton still remains as major crop of the district.

KEY Words : Cropping pattern, Compound growth rate, Productivity, Crop performance

How To Cite This PAper : Gore, N.H., Lembhe, J.V. and Kolekar, P.L. (2015). Performance of major crops and changes in cropping pattern in Akola district. Internat. Res. J. Agric. Eco. \& Stat., 6 (2) : 382-385. 